\title{
The empathy during the training of the dentistry at the Universidad Autonóma de Sinaloa
}

\section{La empatía durante la formación del odontólogo en la Universidad Autonóma de Sinaloa}

\author{
LÓPEZ-PÉREZ, María Carlota†
}

Facultad de Odontología de la Universidad Autónoma de Sinaloa

ID $1^{\text {st }}$ Author: María Carlota, López-Pérez / ORC ID: 0000-0002-6752-1738

DOI: $10.35429 / J T E R .2020 .17 .6 .30 .49$

Received February 14, 2020; Accepted April 01, 2020

\begin{abstract}
In this paper, the first part of the investigation of the level of empathy of dental students of the Autonomous University of Sinaloa by school grade and gender is presented, implementing the Workshops of Interpersonal Relationships and Self-Esteem (RI and A), with the support of Human Development and the Person-Centered Approach as an educational strategy to foster the development and strengthening of the level of empathy of dentists in training. This research was non-experimental, transectional, exploratory and descriptive with a mixed approach. The Jefferson Medical Empathy Scale in its Spanish version was applied in the first stage to 364 students and adapted to training dentists investigating their level of empathy. The results of this first stage of the first and third year female gender presented a higher score in level 2 of empathy. It is important that, in addition to recognizing the empathic level in the dentist-patient relationship, educational strategies and continuous training that foster their personal development, including a positive impact on the interpersonal relationships they establish with their patients, are included in the professional training of dentists.
\end{abstract}

Empathy, dentistry, health, students, teaching

\section{Resumen}

En el presente trabajo se presenta la primera parte de la investigación del nivel de empatía de los estudiantes de odontología de la Universidad Autónoma de Sinaloa por grado escolar y género implementándose la realización de Talleres de Relaciones Interpersonales y Autoestima (RI y A), con el sustento del Desarrollo Humano y el Enfoque Centrado en la Persona como estrategia educativa para fomentar el desarrollo y fortalecimiento del nivel de empatía de los odontólogos en formación. Esta investigación fue de tipo no experimental, transeccional, exploratorio y descriptivo con enfoque mixto. Se aplicó en la primera etapa a 364 estudiantes la Escala de Empatía Médica de Jefferson en su versión en español y adaptada a los odontólogos en formación investigando su nivel de empatía. Los resultados que arrojo esta primera etapa el género femenino de primero y tercer año presentaron mayor puntaje en el nivel 2 de empatía. Es importante que además de reconocer el nivel empático en la relación odontólogo-paciente se incluya en la formación profesional de los odontólogos estrategias educativas y capacitación continua que fomente su desarrollo personal buscando un impacto positivo en las relaciones interpersonales que establecen con sus pacientes.

Empatía, odontología, salud, estudiantes, docencia

Citation: LÓPEZ-PÉREZ, María Carlota. The empathy during the training of the dentistry at the Universidad Autonóma de Sinaloa. Journal of Teaching and Educational Research. 2020. 6-17:30-49.

\footnotetext{
$\dagger$ Researcher contributing as first author.
} 


\section{Introduction}

Education in Mexico is undergoing constant changes in its structure and in its teaching methods, from the basic level to the higher level, thereby seeking to train trained professionals who respond to the demands of society by providing satisfaction in the services provided. Proof of this is the Faculty of Dentistry of the Autonomous University of Sinaloa, a higherlevel educational institution which since its origin to date has had important changes both in its curricular structure and in its teaching methods.

Guerra (2013) comments that the career of dental surgeon at the Autonomous University of Sinaloa (UAS) has its beginnings in 1978 responding to the need to have oral health professionals in the northwest region of the country, the educational model was modular (The courses are organized by modules, defined by multi and interdisciplinary transformation objects). Since then, the curriculum has been modified on several occasions, adapting itself to the times and educational processes of our contemporaneity.

There is no doubt that changes in educational plans are always present in the training of professionals and it becomes evident that in health areas where the primary pillar is patient care, important aspects of these processes stand out, especially in this case. Particularly in which empathy is studied which in this field of health is considered an essential requirement to achieve an effective dentist-patient relationship and where unconditional acceptance of individual differences and careful listening form the pillars to achieve understanding pain, feelings and / or mood of the patient trying to put himself in his place with tolerance and positive attitude.

That is why the health sciences demand extensive theoretical, practical and attitudinal knowledge which should be developed during their training process; however, attitudinal training becomes difficult to teach in students when it is not empathically transmitted by teachers and where the rescue of values conceived in the family is not reflected in positive attitudes or they act wrongly when interacting with the patient.
From this context, this research based on the mixed method emerged, which was carried out with students from the School of Dentistry in the afternoon shift at the Autonomous University of Sinaloa during the period from September 2014 to May 2015.

\section{Problem statement}

\section{Definition and limitation of the problem}

Empathy is part of the socio-emotional intelligence model that integrates interpersonal skills, in turn, it is defined as the ability to be aware and understand the emotions, feelings and ideas of others, which is why it is considered a cognitive component (Fernández, López \& Márquez, 2008).

Hojat and Mangione (2001) consider the development of interpersonal skills the backbone of empathy, and say that it is an important element of professionalism in medical, dental and any other teaching and practice in the area of health.

In this sense, it is known that the pedagogical practice of educational institutions in the health area, such as dentistry, is focused on promoting the merely cognitive and procedural aspects, avoiding important affective and cultural aspects, which leaves them at a disadvantage. the dentist-patient relationship greatly decreasing the achievement of goals.

That is why, in the dentist-patient relationship, having knowledge and developing empathic skills acquires great importance, since the dentist from the first moment of interaction with the patient will use these skills, thereby providing a climate of trust, certainty and success in dental treatment (Prabhu, Kumar, Prasanth \& Kishore, 2014). In the dental practice clinics of the Autonomous University of Sinaloa, it is observed that the students receive the patient, place him in the chair and on many occasions begin to work in dental treatment without covering the minimum conditions of care such as ; clinical interview, speaking to the patient by name, directing the conversation by asking clear and sufficient questions, activating careful listening, unconditional acceptance, activating the ability to observe in non-verbal language, corroborating after the messages have been received correctly in order to develop the proper diagnosis and treatment plan. 
The teacher's intervention is to make the student aware of the importance of the dentistpatient relationship, since the attitude depends more directly on the will of the person, which is known to be compromised for various reasons such as fear, insecurity or the lack of motivation, that is, the attitude is modifiable (Gallardo, 2011).

That is why in the UAS Faculty of Dentistry the subject of medical psychology is taught in the fifth semester of the degree program, whose objectives are that students learn, develop and apply empathetic skills when attending to patients in their clinical practices; however, taking this subject has not been enough for students to endorse the knowledge taught in it and to achieve the value and meaning to apply it naturally when interacting with the patient.

Howard, Navarro, Rivera and Zamorano (2013) comment that the learning of the dental career includes the acquisition of knowledge in the area of basic and medical sciences, but in many occasions the skills related to emotional intelligence such as empathy.

Suardíaz (2011) says that the search for the passage to a true human conception is in the intersubjective since the contrast between apathy and empathy implies opening up to a different way of structuring for a healing relationship between a health server and his patient. While apathy implies an inability to feel and accept the signs of illness, conversely empathy implies the ability to put oneself in the situation of the other, which makes him feel in the world as he feels, thus exercising his exercise in a professional way alongside the sick.

These fundamental aspects for the future dentist should be present in a cross-sectional way throughout the entire career, constituting a basic framework on which the knowledge and skills imparted using different disciplines such as bioethics and dental psychology, among others, are founded (Oviedo , 2011).

Bazerque (Quoted in Aguas and Castiglia, 2010) talks about and comments on the four universally accepted principles of the ethics of the practice of health professions:
The first principle is respect for autonomy (freedom), which passes from the paternalistic perspective of the health professional to that of the patient, who has the right to choose or reject a certain treatment, which influences their quality of life beyond of its therapeutic value.

The second principle (fraternitysolidarity), the "primum non nocere", for modern health care, the first thing is not to harm.

The third principle is beneficence (fraternity solidarity), where the patient has the right to the best treatment.

And finally, there is justice (equality) where there is talk of the equitable distribution of health resources, where research in its field with the participation of patients is only justified if there are reasonable possibilities that the population on which it is investiga can benefit from the results.

That is why it is necessary to highlight the importance of the communication skills of health professionals, since they encompass crucial aspects when caring for a patient, giving them information, understanding their perspective and relating to them. Remor, Arranza and Ulloa (cited in Jaramillo 2009) insist that patients and family members want to perceive that the professional who cares for them is competent, that their behavior reflects sensitivity, warmth and concern for them and thus they will feel more satisfied with professionals who do not are emotionally neutral.

\section{Theoretical framework}

\section{Conceptual framework}

Empathy, was pointed out many years ago by Rogers, as a primary attitude within assertive relationships, as well as careful listening, unconditional acceptance, as well as authenticity or consistency. Various studies of different therapeutic orientations have shown that there are significant positive associations between these attitudes and the results of the treatment, also these associations are clearer when they are evaluated by the patient regarding the treatment received (Bados \& García, 2011). 
Gutiérrez, (2005), comments that for Rogers, empathy is the ability to perceive another person's internal frame of reference accurately, seeking to feel the same as the other person but without losing their own condition, assuming at the same time that empathy It is not a psychological or emotional experience, nor a psychic leap into another person's mind, but an openness and respect towards the other.

Garza (1996) says about the concept; Accepting and respecting another person without judging, labeling or making value judgments based on their behavior, is already unconditional positive acceptance as an important part of the basic attitudes of empathy as well as consistency, and that to be consistent is to be oneself, which implies acting in correspondence with what is thought, felt, valued, known or ignored. Being consistent means being a genuine, open, authentic and free person in each of the human relationships that are established.

In the context of the health area, empathy acquires great importance when interacting with the patient and is described as a concept that encompasses cognitive, affective and emotional development, where the cognitive domain implies the ability to understand the experience of the world Inside others, the affective domain refers to celebrating or participating in the experience of the feelings of the other and the emotional domain to the subjective responses obtained by affinity with other people (Oviedo, 2011). Hojat (2011) expresses that, from this empathic relationship, and good communication is achieved, that the health professional obtain a greater therapeutic alliance, better satisfaction, trust and acceptance of the patient.

At the same time, Gutiérrez (2005) comments that philosophy is interested in the essence of knowledge and psychology is interested in the knowledge process, two indispensable and constantly strengthening situations in any profession in which interpersonal relationships intervene, says that education understood in the broadest sense, it is oriented towards the integral, harmonious development of the person, which is why it must cover all aspects in the different stages of human life, so as not to refer only to simple intellectual instruction or transmission of information and knowledge imparted in the classrooms of educational institutions.
Psychology and sociology are fundamental pillars in the formation of the personality aspect of the future health professional where empathy is very important for the development of interpersonal relationships and facilitates competence in communication, the main dimension of quality within professionals from the health area.

Aguas and Castiglia (2010) say that, in the world of human values, art is easily universal, the same not happening with ethics or morals since these have important religious and cultural differences. And in turn they comment that evolution allows the subsistence of only those behaviors that do not go against survival and reproduction, that when living in groups forming a society, egoism must be limited that individual desires must be put in synergy with the social moral feelings, of empathy and sympathy, that lead to altruism, visible in many species, including ours where empathy is the ability to represent the mental states of the other and to recognize differences with one's own.

Van Manen (2010) explains the importance of having tact and sensitivity, as well as a conscious perception when relating to students, for which he points out that a person who has tact possesses the ability to know how to interpret thoughts, feelings and interior desires through indirect keys such as gestures, behavior, expression and body language.

Undoubtedly, studies on empathy in the training of students in the health area have become sources of data, information and realities in their praxis, with which and through the findings found, it has allowed the implementation of mechanisms essential in rectifying or maintaining the training of solidly empathetic professionals.

Psychology considers, like sociology, the interest in returning to the socio-affective aspect of the human being, trying to discover the conditions on which the success of interpersonal relationships depends, where empathy is an essential part, which is why It is convenient to know the importance of empathic relationships in the training faculties of professionals in the health area (Gutiérrez, 2005). 
In this regard Hojat and Mangione (2001) carried out and published in Philadelphia Pennsylvania in the United States one of the first papers on empathy, they presented it on a large scale carried out at Thomas Jefferson University, with medical students, residents, nurses and doctors exercising using the Jefferson Medical Empathy Scale (EEMJ) and where preliminary results indicated that women are more likely than men to be empathetic and that practicing physicians are more technology-oriented rather than patient-oriented, likewise found that the most advanced grade students show a decrease in empathy.

Later Hojat, et al., (2002) group of medical education researchers at Jefferson Medical College recognized the need for an instrument to measure empathy in the context of medical education and patient care, so they set out to investigate empathy in 371 third year medical students during two academic periods, applying the EEMJ. In particular, they managed, on the one hand, to confirm the hypothesis that medical students with a higher empathy score (120) would obtain higher scores in the clinical practice competition; conversely, students with low empathy scores (115) did not receive high scores in the six basic third-year clinical rotations. Therefore, they believe that empathy in the context of health care can be defined as the ability to understand the experiences and feelings of patients and recognize the development of interpersonal skills as the backbone of empathy, considering it a Important element of professionalism in medical teaching and practice.

Chen, Kirshenbaum, Yan, Kirshenbaum, \& Aseltine (2012), carried out at the Boston University School of Medicine, Boston, MA, USA in 2006, a cross-sectional study of 658 students with the objective of measuring and examining student empathy through the years of study in medical school, using the Jefferson Medical Empathy Scale in its version for students as a measurement instrument. Obtaining as results that the first year students presented higher empathy scores while the fourth year students had the lowest scores.
The results of the study in question drew attention since the student reported more empathy in his pre-clinical years than in the clinical years and invited to ask himself the question of what happens in the course of medical education and proposes that research is necessary to confirm what was found and to design interventions to mitigate this impact, since it is of great interest to keep in mind that empathy is important in the doctor-patient relationship and has clear benefits for the patient and the doctor.

Schwartz and Bohay (2011) conducted a study at the Schulich School of Medicine and Dentistry at the University of Western Ontario, where student perspectives were examined to determine the impact of new educational methodologies designed to integrate patient voices, (of the management or attention given by the doctor or dentist), through videos where patients describe their experiences and are exposed in a series of conferences.

After this, the students have had to make of these videos a reflection journal on the topics seen. The results of the study indicate that students perceive this innovation as an improvement for the teaching of professionalism. They also comment that this raised their awareness of the importance of empathy and the lecture course was very well received by all students.

Alonso and Kraftchenko, (2003) at the Faculty of Medical Sciences, Matanzas, Cuba, carried out a descriptive study of doctor-patient communication as part of ethical-professional training for 124 students and 43 professors from different years of the career and in which Empathy was part of the three communication functions analyzed and where it is considered as a mechanism for mutual understanding. Among the results obtained, some researchers consider that there is a limited contribution of the teaching process to achieving adequate doctor-patient communication in students, which is associated with insufficient ethical-professional training. 
Also Beattie, Durham, Harvey, Steele, \& McHanwell, (2012), at the Faculty of Dental Sciences, Newcastle University, UK examined the level of empathy of 66 freshmen in a before and after course on behavioral sciences that are taught before they attend patients, using the EEMJ as an evaluation instrument and resulting in a significant increase in the EEMJ measures pre and post course, which led to the conclusion that the Jefferson Empathy Scale has potential usefulness in evaluating the cognitive-affective aspect of empathy and that professionalism is a central principle of the dental curriculum, and in this sense empathy should be considered as an important component of attitude, for which reason they recommend that observational studies to investigate dental student attitudes, and the role of teaching models deserve further investigation.

Similarly, Rivera, Arratia, Zamorano, \& Díaz, (2011), in the analysis carried out at the Faculty of Dentistry of the FinisTerrae University of Chile in 2009, to assess the level of empathic orientation in the third, fourth and fifth year students, the Jefferson Medical Empathy Scale was applied, resulting in the scores obtained in the (EEMJ) being higher in the most advanced levels of the career. Women have higher scores than men at the different levels studied. These men present greater increases in the scores obtained at the same levels evaluated. Given these results, it was concluded that third, fourth and fifth year dental students have a high level of empathic orientation. That women show fewer changes in the levels evaluated, while men show a greater development of their level of empathic orientation.

For his part, Oviedo, (2011) in the crosssectional descriptive study carried out at the Faculty of Dentistry at the University of Carabobo, in Madrid, with 675 dental students and where the objective was to analyze the degree of empathy that students in training have. first, third and fifth year, using the Jefferson Scale of Empathy in Spanish and adapted to students as a tool, found that the empathy of first-year students is significantly less than that of third-year and fifth-year students. just like the factor taking perspective and caring with compassion.
Continuing with the above, the lowest score was obtained by the factor putting yourself in the patient's place and was similar in the first, third and fifth year students. The empathy obtained by female students did not differ statistically from male students for the study population. One of the conclusions they reported was the need to cultivate throughout the professional training the ethical humanistic aspects with empathy as a fundamental pillar of positive dentist-patient relationships.

Likewise, Chew, Zain, \& Hassan, (2013), studied at the University of Malaysia, 163 medical students under a cross-sectional study, using a scale on Emotional Intelligence as a tool, examining its effect on academic performance of medical students in the first and last year of the degree. The results here denoted that the students who had better Emotional Intelligence obtained better results in the continuous evaluations and in the final exam. Therefore, they concluded that the development of emotional skills can improve the academic performance of medical students.

In Malaysia, Babar, Omar, Lim, Khan, Mitha, Ahmad, \& Hasan, (2013) carried out a study with the aim of analyzing the validity and reliability of the Jefferson Medical Empathy Scale in its version for "S" students in a sample of dental students from Malaysia, the secondary objective was to assess the level of empathy in the first and last year of the degree course in 441 dental students from public universities and 141 students from private universities in Malaysia.

The results of the previous study showed a good internal consistency of the Jefferson Empathy Scale in its three factors, as well as that those of the masculine gender reported a higher empathy score than the feminine ones, in the same way the fourth year students presented more scores. high empathy and students from public universities were more empathetic than those from private universities. Among the conclusions, these authors suggested that, in future studies of empathy in students, they be made longitudinally in order to explore changes throughout the career years. 
Costa, Alves, Neto, Marvão, Portela, \& Costa, (2014), in a multi-institutional crosssectional study carried out at the University of Minho, Braga, Portugal, where 472 students from three medical schools participated seeking the existing association between empathy and personality of medical students using, among other tools, the Jefferson Empathy Scale (EEMJSPV) adapted to students from Portugal, finding that there is an association in these schools between the dimensions of friendliness, openness to experience and empathy since the personality of These contributed significantly to identifying the most empathetic students. Therefore, they recommend that medical schools should pay attention to the personality of the students in order to understand how to improve empathy and contribute to increasing the chances of achieving greater adherence to treatments, better health results and greater patient satisfaction.

For his part, Casabuenas (2007) in a study carried out at the Autonomous University of Barcelona, where the objective was to analyze the conversation of 39 participants during the doctor-patient interview in a primary care center in the province of Barcelona, they sought to identify the verbal and non-verbal expressions manifested by the patient, in addition to knowing if the doctor recognizes these expressions, identifies them and somehow responds to them, concluded that doctors have to improve communication skills, as well as their skills in identifying and managing own and other people's emotions, in addition to applying these skills in daily clinical practice since the results of their research identified a lack of empathy, attentive listening and unconditional acceptance by the health professional towards the patient.

In this regard, a study by Khademalhosseini, Khademalhosseini, \& Mahmoodian, (2014) was published in the Journal of Advances in Medical Education \& Professionalism, carried out on medical students from the first to the seventh year of study at the Shiraz School of Medicine (South of Iran) in 2010, where the Iranian version Jefferson's Empathy Scale was applied. According to the results obtained by these authors, they concluded that the students generally had a low level of empathy, which caused them great concern and made them suggest courses on empathy as a possible inclusion in the curriculum, and said that interpersonal skills and communication
They are considered a very important proficiency index for medical students and medical residents.

On the same subject in Mexico, a study by Alcorta et al. (2005) was found in the Faculty of Medicine, of the Autonomous University of Nuevo León, Monterrey using the Jefferson Empathy Scale in 1022 medical students (494 women and 528 men) with the " $S$ " version of the EEMJ-S designed to measure empathy in medical students, obtaining results of the exploratory analysis of the three factors, "domain of perspective taking", "domain of care with compassion" and "Mastery of the ability to put yourself in the patient's shoes. "Concluding that as long as the doctor is willing to understand what the patient thinks and feels, the better the care he will offer in this way will make empathy an indispensable means of the doctor-patient interpersonal relationship. In this research, measuring empathy is the first step to examine your level of permanence from the time you enter your degree to the moment of choosing a medical specialty since it also allows you to analyze the impact of educational strategies aimed at increasing empathy, with potential benefits for the professional development of the doctor and the health of his patient.

Gallardo, (2011) also carried out a study in the Faculty of Medicine of a terminal line in Education, of the Autonomous University of Querétaro with the aim of corroborating the change of Attitude in the doctor-patient relationship in residents of Family Medicine, this later to an educational intervention in bioethics with a participatory and reflective approach. Where they concluded that it is possible to improve the doctor-patient relationship, communication and empathy of residents through educational intervention in participatory and reflective bioethics. 
In turn, García, (2013) from the Autonomous University of Mexico in support of the 249 Family Medicine Unit in Tlaxcomulco, State of Mexico, conducted a study of 20 attached doctors and 260 patient users of that unit, applying the Jefferson scale to evaluate The perception of the patient regarding the empathy of their doctor in that family medicine unit, within the results obtained, it was found that health professionals with an age between 31 and 35 years presented better empathy than those of 51 years in Going forward, regarding the score according to the specialty was not significant, therefore they said that this could be related to the fact that the family doctor and the general doctor would have to have better behaviors to improve their communication with the patient and therefore their medical performance, They also reported on the years of working life, concluding that the level of empathy remains stable during the first years of form ation and professional practice and then decreases.

Márquez (2014) using Jefferson's perception of empathy scale for patients in the Family Medicine Unit 66 of Xalapa, Veracruz, where his objective was to correlate the satisfaction of the doctor-patient relationship with the level of empathy of the physician and the perception of this for the patient. Concluding that patient satisfaction is a measure of health care outcome, and that it is generally at moderately high levels, interpersonal exchanges between physician and empathically compromised patient have been shown to improve medical practice and help to heal. So the first step that the doctor must take to humanize care in health areas, is to admit that he must first humanize himself, reflecting to find ways and resources that allow him to integrate science with humanism than the practice of health requires.

In this regard, Márquez (2014) argues; Many times the doctor stops visiting the arts and the humanities and deprives himself of other ways of knowing the world, people, things; he loses the ability to admire himself and feel that most of the phenomena that surround him do not depend on him. This break between the professional being and the human being, even having catastrophic consequences, is not intentionally caused. Perhaps that is why, because it is not something that one chooses, one does not feel responsible for it, and sees it as something imposed by the system, or by the natural evolution of medical practice. (p.12)

ISSN-2444-4952

ECORFAN ${ }^{\circledR}$ Todos los derechos reservados
As pointed out in the various investigations carried out, some authors recommend that health educators design additional strategies that improve reflection and empathic behavior in students, specifically in clinical practice, to become a role model, thus achieving ultimate goal which is to improve the quality of patient care.

\section{Methodological framework}

\section{Design and approach}

Hernández and Mendoza (2008) refer to the fact that the research design is the action plan that is followed to meet the stated objectives and corroborate the hypotheses. In relation to this, the present study is of non-experimental design, since it is carried out without deliberately manipulating the study variables, it is limited to observing the phenomenon as it occurs in its natural context and then analyzing them, this design is basic for mixed studies.

Where, Pulido (2014) for his part says, that qualitative research tries to identify, basically, the deep nature of realities, their dynamic structure, the one that gives full reason for their behavior and manifestations and the qualitative (which is the whole integrated) is not in any way opposed to the quantitative (which is only one aspect), but implies and integrates it, especially where it is important. He also says that qualitative research is an activity that locates the observer in the world, it consists of a set of interpretive practices that make the world visible. These practices transform the world, turning it into a series of representations, including field notes, interviews, conversations, photographs, records, and memoirs.

In relation to this, the scope of an investigation is based on the data collection and sample selection strategy, and may have more than two research scopes, therefore, this investigation is a cross-sectional or transectional study. Because it collects data in a single moment, likewise exploratory studies, serve to make a diagnosis and precede the descriptive scope, which are the proper basis for such research. 
The great complexity and uniqueness of many of the human phenomena make it impossible for there to be a rigid and preestablished modality of qualitative research, qualitative research is, in essence and inevitably, multi-method and plural (Crisol, 2011).

In this sense, quantitative research arose in the 18th and 19th centuries, in the process of consolidation of capitalism and within western bourgeois society. From its origins its purpose was to analyze social conflicts and the economic fact as a complex universe. Inspired by Newtonian natural sciences and physics based on Galileo's knowledge (Mendoza, 2006).

The main characteristic of this methodology is that it allows the data to be examined numerically, especially in the field of statistics. Mendoza (2006) says that for there to be a quantitative methodology, it is required that among the elements of the research problem there is a relationship whose nature is linear, that is, that there is clarity between the elements of the research problem that make it up, that it be It is possible to define it, limit them and know exactly where the problem begins, in which direction it is going and what type of incidence exists among its elements. These elements are called variables, relationship between variables and unit of observation.

Hernández, (2008) argues that today we cannot approach complex phenomena from a single perspective and discipline, and that is the reason why the need to use the mixed approach or method arises, since the vision of these methods is interdisciplinary and they arose due to the complexity of certain phenomena under study such as;

Human relations

\section{Diseases}

2. The Teaching

3. The media, among others.
In the field of educational research, mixed studies have been multiplying rapidly, proof of this is the note that in October 2003, appears in the prestigious publication Brilish Educational Research Journal, which edited a special issue to celebrate and include "some of the best recent studies" in the field of educational research, eight in total, of which six were mixed (Scott , 2007).

\section{Population and sample}

The population was made up of the total number of students from first to fifth year of the afternoon shift of the dental faculty of the Autonomous University of Sinaloa, located in a university city, in Culiacán, Sinaloa, Mexico.

\section{Criteria for inclusion and exclusion of the sample}

The type of sample used in this investigation was of convenience, also called as deliberate selection, since it is the one that is available at the time or period of the investigation and consists of the choice by non-random methods whose characteristics are similar to those of the population. Here the sample is made up of those that are most convenient, the closest individuals are selected to participate and the process is repeated until the desired sample size is obtained (Espinoza, S., 2016).

In the inclusion criteria, all those students who were willing to participate and were in direct interaction with patients in clinical practice were taken into account, therefore, all those students who voluntarily decided not to participate despite being current in clinical practice with patients.

\section{Subjects and scenario}

This research was carried out with students from the afternoon shift of the Faculty of Dentistry of the Autonomous University of Sinaloa, located in Ciudad Universitaria, in the city of Culiacán, Sinaloa, Mexico, in the period from September 2014 to May 2015 .

The investigation was carried out in three stages:

First stage (Diagnosis). 364 students from first to fifth year participated in it, of which 244 were women and 120 were men of bachelor's level. 
The objective in this diagnostic stage was to measure the level of empathy, both gender and educational level.

Second stage (Workshop and Interviews). For the workshops, the sample consisted of 92 third-year students, of whom 64 were women and 28 men. And 14 students participated in the interviews, 8 of whom were women and 6 men.

Third stage (Observation and application of scale to patients) for observation was carried out with three pairs of students and one patient in each case, and 48 patients participated in the application of the patient perception scale, 29 of whom were women and 19 men.

\section{Techniques and instruments of data collection}

The survey technique was used with the application of the Jefferson Empathy Scale in its Spanish version and adapted for students in training (EEMJ-S) recovered from Oviedo (2011), Annex 1. As an instrument to establish the level of empathy of students from first to fifth grade on the afternoon shift.

\section{Process}

Initial diagnosis: Application of the Jefferson Empathy Scale in its Spanish version and adapted to students in training (EEMJ-S). In September 2014, at the UAS School of Dentistry located in Ciudad Universitaria de Culiacán, Sinaloa, permission from the Faculty management was requested to carry out this research, explaining in detail its purpose. Once the permit was authorized, the first stage of the investigation was carried out, visiting the students from first to fifth year of the afternoon shift, with the aim of measuring the level of empathy, both by gender and by educational level. In their respective classrooms the purpose of the research was explained to a total of 364 students from first to fifth grade of the afternoon shift (244 women and 120 men). Before starting the study, participants were explained that the questionnaire was about empathy, asking for their personal beliefs and opinions, it was also said that participation was voluntary and that individual responses were confidential and would not be part of their academic record.
After this, the instrument (EEMJ-S) was delivered in its Spanish version and adapted to dental students (Annex 1), the participants wrote down their telephone number and / or email for their participation in the second stage.

Once the instrument was answered, we proceeded to collect it, thanking them for their participation.

\section{Analytical framework}

Analysis of results.

The first stage consisted of carrying out the diagnosis with students from first to fifth year in order to investigate the level of empathy in both gender and grade level. In this stage, the Jefferson Empathy Scale in its "S" version (EEMJ-S) Annex 1 was used to measure the level of empathy in dental students, which evaluates under three factors (perspective taking, compassionate care and the ability to put yourself in the patient's place) it should be noted that the term Factor, was modified for this investigation with the name of Level, as shown in (Annex 2) where the EEMJ-S questions are found for each level of empathy.

This instrument (EEMJ-S) has 20 elements, of which 10 are in the positive and 10 are in the negative sense. Their total score varies between 20 and 140, the highest values indicating a behavioral trend of greater empathic commitment to the patient. Respondents indicate their level of agreement to each element on a seven-point Likert-type scale, where $1=$ strongly disagree and $7=$ strongly agree.

An adequate survey response is defined as having 16 or more of the 20 items on the scale. Therefore, surveys with less than 16 answered questions were discarded from the analysis. The ten elements in the positive sense correspond to the first factor taking empathy perspective and of the ten elements written in the negative sense, seven measure the second factor of compassionate attention and three measure the third factor of the ability to in the patient's place "(Oviedo, 2011).

Analysis of comparisons of levels of empathy first stage. 
In the data processing for analysis, descriptive statistics were applied, based on the distribution of absolute and relative frequencies (percentages), measure of central tendency, arithmetic mean and measure of variability, as well as standard deviation. For the indices and indicators derived from inferential statistics, the one-way ANOVA test and Fisher's F test were used, which were calculated to examine differences in empathy scores related to gender and year of study.

Both descriptive and inferential statistical data analyzes were formed using the SPSS version 18 package with 0.05 as the significance level. For the tabulation of the results, the scores obtained in the questions in the negative sense were inverted using the $8 \mathrm{X}$ formula in which $X$ is the assigned value of the question, to positivize the result, and thus achieve that the final average of all the questions has a direct correlation to the level of empathy (Oviedo, 2011).

Because it was the diagnostic stage, it was decided to include all the grades, 364 dental students participated in this stage, the purpose was to have a broad overview of the prevailing situation regarding the knowledge and use of empathy among dentists in training.

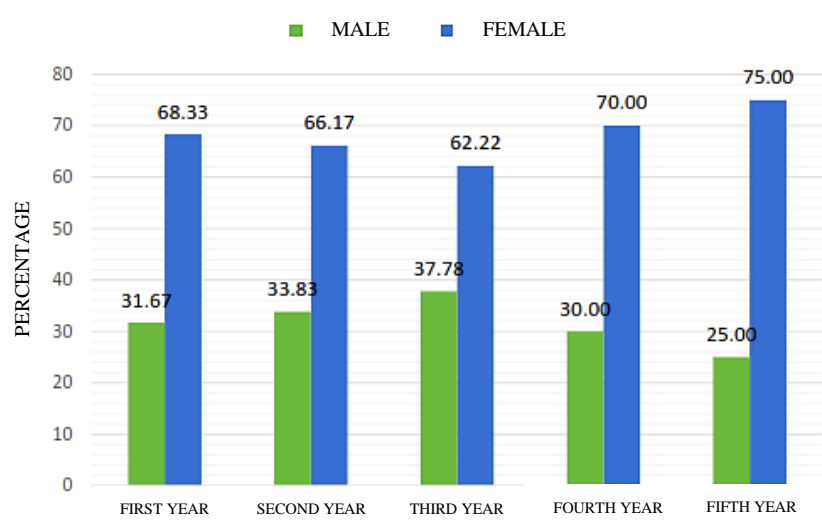

Figure 1 Toral of students participating in the diagnostic stage. FOUAS, 2014

Source: own elaboration, 2015

Figure 1 represents the distribution of the students subject to study according to the years of school and gender, it also shows that in the FO student population of the UAS the female gender predominates $(67 \%)$ in all academic grades and that the male population $(33 \%)$ is decreasing as they progress towards the end of the degree.
In figure 1, where the distribution of participants by school grade is shown, of the 60 first-year students, 19 (31.67\%) were male and $41(68.33 \%)$ were female. Regarding the second year, of the total of 201 students who participated, $68(33.83 \%)$ were male and 133 $(66.17 \%)$ were female. In the third year, a total of 45 students participated, of which 17 $(37.78 \%)$ were male and $28(62.22 \%)$ were female. The fourth-year students who participated were a total of 30 students, of whom $9(30 \%)$ were male and $21(70 \%)$ were female. Finally, the fifth year is shown, in which a total of 28 students participated, of which 7 (25\%) were male and $21(75 \%)$ were female.

Before continuing and presenting the results of levels of empathy and in order to specify the characteristics that each level of empathy contemplates according to the EEMJ$\mathrm{S}$, taking into account the contributions made by Oviedo (2011) where he mentions, that in the In the context of health, empathy is described as a concept that encompasses cognitive, affective and emotional development, and as this is an investigation in the area of health, each level of empathy was conceptualized for this investigation:

Level 1 of empathy (perspective taking). At this level, the student will demonstrate being able to attend to the patient from his perspective, trying to think like him, understanding his feelings to achieve a good relationship in the search for a therapeutic strategy that favors the success of the treatment. At this level the student makes use of his cognitive development.

Level 2 of empathy (Attention with compassion). At this level the student will demonstrate that he has the capacity and ability to pay attention to the experiences of his patients, understanding and understanding them as an integral part of dental diagnosis. At this level, in addition to cognitive development, the student incorporates the affective ingredient into the relationship with his patient. 
Empathy level 3 (Ability to put yourself in the patient's place). At this level the student will demonstrate that he is able to establish an empathetic relationship with his patients by showing interest in their well-being, demonstrating openness to dialogue, attentive listening, with unconditional positive acceptance and flexibility to adapt to individual differences, thus demonstrating an attitude empathetic towards the patient and their relatives. Both cognitive, affective and emotional development are fused at this level.

In Table 1 and Figure 2, the general average of empathy is presented, as well as by levels according to the results of the application of the EEMJ-S in the students of the faculty of dentistry of the Autonomous University of Sinaloa.

\begin{tabular}{|l|c|c|c|}
\hline $\begin{array}{l}\text { General } \\
\text { empathy }\end{array}$ & $\begin{array}{l}\text { Level } \mathbf{1}= \\
\text { Factor } \mathbf{1}\end{array}$ & $\begin{array}{l}\text { Level } \mathbf{2}= \\
\text { Factor 2 }\end{array}$ & $\begin{array}{l}\text { Level } \mathbf{3} \\
\text { Factor 3 }\end{array}$ \\
\hline $103.4 \pm 13.04$ & $58.3 \pm 7.41$ & $33.3 \pm 8.35$ & $11.8 \pm 3.71$ \\
\hline
\end{tabular}

Table 1 Level of Empathy in Students of the Faculty of Dentistry, UAS, 2014

Source: own elaboration, 2015

Table 1 and Figure 2 reveal that the level that presented the highest score was level 1 of empathy (Perspective taking) followed by level 2 (Attention with compassion) as well as later level 3 (Ability to put yourself in the patient's place ). These results are revealing in that most of the students are at a level of cognitive empathy where they try to understand their patient seeking to gain their trust so that they can carry out dental treatment.

Likewise, just under half show that according to their responses they have the capacity and (affective) ability to understand and understand their patients, and a minority feel (emotionally) capable of establishing an empathetic relationship with their patient. . In this regard, Casabuenas (2007) comments that doctors have to improve communication skills, managing their own and other people's emotions to correct their clinical practice.

Analysis of empathy levels in dental students by first stage school grade.
In the statistical analysis to know the level of empathy according to EEMJ-S of the different school grades of the students of the UAS School of Dentistry, Table 2 and Figures 3 and 4 show that the general average of students showed that they did not exist significant differences between the general level of empathy and school grades, but when analyzing the results by levels, it was found that third-year students $(37,044 \pm 7,192)$ followed by first-year students $(34,733 \pm 9,536)$ showed high scores at level 2 of empathy (Attention with compassion) $(\mathrm{F}(4,359)=4.25 ; \mathrm{p}=0.002)$.

This was striking, since the first-year students still do not have direct interaction with patients, which indicated that the results were probably emitted from cognitive development in the assumption of how empathetic treatment should be with the patient and family members of the same during the dentist-patient relationship.

In the case of third-year students, it could be argued that their knowledge on the subject of empathy and empathetic interpersonal relationships in the treatment of the patient was present because it is at that grade level when they are studying the subject of medical psychology, which is the educational program that contemplates these learning.

In addition, it was striking that in the fourth and fifth year the scores decreased, which led to the assumption that students require continuous training on topics that address empathy, its importance and use, in order to stay motivated towards the practice of empathetic relationships with his patients.

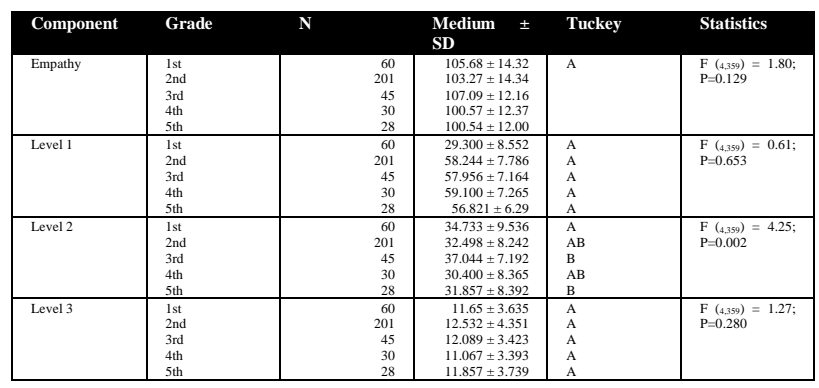

Table 2 Level of Empathy in Students of the Faculty of Dentistry, by Grade, 2014

Source: own elaboration, 2015 
Table 2 represents the general average that shows that there are no significant differences between the degrees of study ( $\mathrm{F}$ $(4,359)=1.80 ; \mathrm{p}=0.129)$, also level 1 (perspective taking) $(\mathrm{F}(4,359)=0.61 ; \mathrm{p}=0.653)$ and level 3 (ability to put yourself in the patient's place $)(F(4,359)=1.27 ; p=0.280)$ did not show significant statistical differences between their general averages, results that are presented in the following figure.

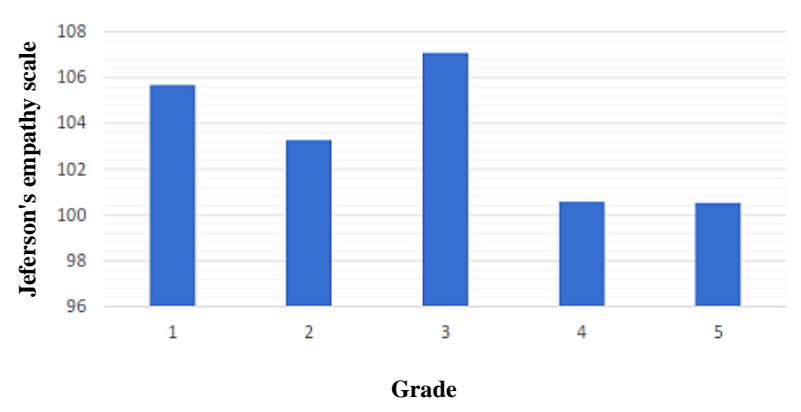

Figure 3 Level of empathy by grade in students, FOUAS, 2016

Source: own elaboration, 2015

In figure 3 the general level of empathy is graphed by school grade, where it is evident that the third-year students in training at the dental school presented the highest score, with the last grades of the degree course having the lowest scores in the level of empathy.

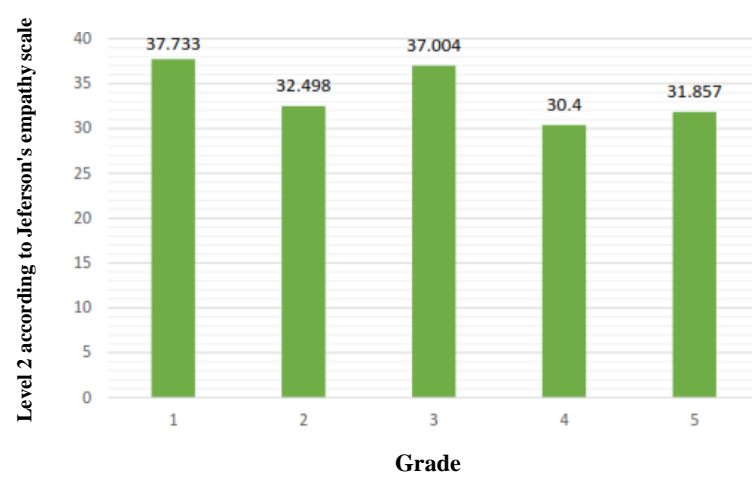

Figure 4 Level 2 of empathy by grade in FOUAS students, 2014

Source: own elaboration, 2015

In Figure 4, Level 2 of empathy is represented according to the EEMJ-S by grade, where students of third and first grade of dentistry from the UAS obtained the highest score, which was thirty-seven percent.

Analysis of empathy levels in dental students according to gender first stage.
In order to know the level of empathy according to the EEMJ-S according to the gender of the students of the dental faculty of the UAS, statistical analyzes of the general average were carried out. The results showed as indicated in the table 3 and figure 5, that the female gender presented a higher level of empathy with respect to the male gender and that in the analysis by levels, level 2 of empathy (compassionate attention) presented the highest score among women with respect to men.

It should be noted that level 1 (perspective taking) and level 3 (ability to put yourself in the patient's place) did not show information with significant differences. Given these data, it was necessary to point out that these could be affected by the evident difference that existed between the student population by gender, where women represented the vast majority $(67 \%)$.

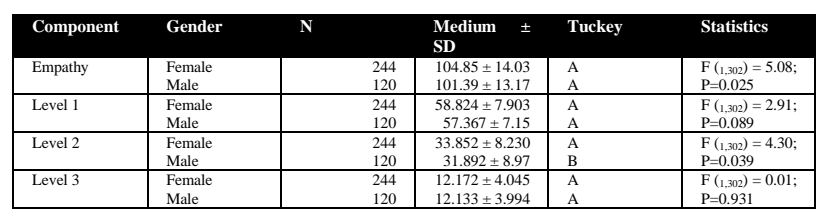

Table 3 Level of empathy in UAS dental students by gender

Source: own elaboration 2015

Table 3 shows the level of empathy by gender presented by dental students at the UAS, where the marked difference between the male and female gender scores is observed.

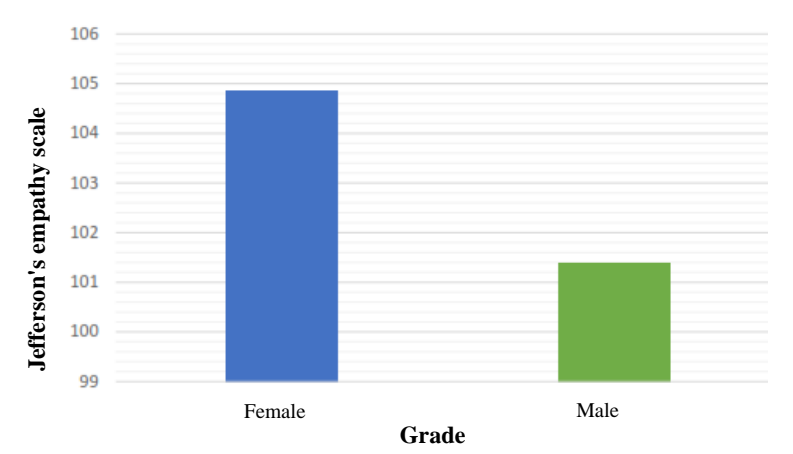

Figure 5 Gender empathy level in FOUAS students, 2015 Source: own elaboration 2015

Figure 5 shows the graphic representation of the significant difference in overall level of empathy according to gender in dental students at the UAS where the female gender presents the highest score. 
It should be noted that the results of the diagnosis provided important data on the objectives established in the research, where it was found that the majority of the student population at the UAS School of Dentistry are women and that they show the greatest empathy with the patient, it was also found that the male population decreases as they advance in the race.

Meanwhile, level 1 of empathy (perspective taking) was the one that presented the highest score in general and by specific levels, it was level 2 of empathy (compassionate attention), the one that prevailed among third and first year students respectively.

These results provided foundations for continuing with a second stage, in the search for elements that support the implementation of educational strategies that favor the development and strengthening of empathy in dental students, since, as Hoffman (2002) argues, empathy is a evolutionary process, a predisposition that develops from childhood to adulthood incorporating the system of social and moral values, also says that the affective and emotional components influence the use of moral principles and the behavior that the subject decides to carry out.

So taking into account all of the above, we proceeded with the second stage of the investigation, since as Ausubel (2002) adds, the human experience not only implies thought, but also affectivity and when considered together, the individual is trained to enrich the meaning of your experience.

\section{Conclusions}

In this research where the first objective was to measure the level of empathy of the students, it was confirmed that the Jefferson Medical Empathy Scale has potential utility to measure empathy in dental students, managing to demonstrate that the average level of empathic orientation obtained by the students of the UAS School of Dentistry it is similar to that of their counterparts in other countries where EEMJ-S has been applied.
It is necessary that subsequent studies consider the perspective of the dentist-patient, in order that both know them, and there is mutual participation, it must be established on the basis of respect and humanized care, as well as listening to the patient in a qualified and To do so participate in the factors that influence dental care and treatment, since the dentist-patient relationship must be linked to the integral vision of the human being.

Future studies, preferably longitudinal in design, should explore the changes in empathy among dental students during their development through their academic training, as well as assess the initiative to implement workshops or elective courses that favor the development and strengthening of empathic interpersonal relationships between teachers-dentists and patients.

It is important to consider that, although the changes are not definitively achieved for those who participate, at least, it is a start for future health professionals to start working with their own emotional health and this allows them later serve your community more comprehensively.

Learning knowledge, content, attitudes and ways of relating are not incompatible, that is why this research sought to make the mission of the UAS School of Dentistry a reality, which is: "To train dentists with academic and human quality, with high ethical sense capable of generating knowledge to contribute to the prevention and cure in the health of the population "(Ramírez, 2011. p.22).

\section{References}

Aguas, S., \& Castiglia, V. (2010). Lo bueno, lo bello y la verdad en Odontología. Revista de la Facultad de Odontología. Universidad de Buenos Aires, 25 (59), 1-2. Recuperado de: www.odon.uba.ar/revista/pdf/rev59.pdf

Alcorta, A., González, J. F., Tavitas, S. E., Rodríguez, F. J. \& Hojat, M. (2005). Validación de la Escala de Empatía Médica de Jefferson en estudiantes de medicina mexicanos. Salud Mental, 18 (5), 57-63. Recuperado de: www.redalyc.org/pdf/582/58252808.pdf 
Alonso \& Kraftchenko, (2003). La comunicación médico-paciente como parte de la formación ético-profesional de los estudiantes de medicina. Revista Cubana EducMedSuper, 17(1), 38-45. Recuperado de: ww.sld.cu/revistas/ems/vol17_1_03/ems04103. pdf

Babar, M. G., Omar, H., Lim, P., Khan, S.A., Mitha, S., Ahmad, S .F. B. \&Hasan, S. (2013). An assessment of dental students' empathy levels in Malaysia. International Journal of Medical Education, 4.doi: 10.5116/ijme5259- 4513Recuperado de: https://www.ijme.net/archive/4/empathy-levelsin- malaysian-dental-students/

Bados, A., \&García, E. (2011). Habilidades Terapéuticas. Departamento de Personalidad, Evaluación y Tratamiento Psicológicos. Facultad de Psicología. Universidad de Barcelona. España Recuperado: diosit.ub.edu/dspace/bitstream/2445/18382/1/H abilidades\%20terapeuticaspdf

Beattie, A., Durham, J., Harvey, J., Steele, J. \& McHanwell, S. (2012). Does empathy change in first-year dental students? European Journal of Dental Education, 16.doi:10.1111/j.16000579.2011.00683.x Recuperado de:

http://onlinelibrary.wiley.com/doi/10.1111/j.16 00-0579.2011.00683.x/abstract

Caceres, O., (2014). Técnicas de investigación entrevista, encuesta y observación. Recuperado de:

http//es.slideshare.net/oscarcaceres9862/técnica s-de- investigación-entrevista-encuesta-yobservación

Cabrera, R. (2012). Investigación Cualitativa: Características, Métodos y Técnicas. Recuperado de: www.psicode.com/resumenes/fundamentos.pdf

Campechano, J., García, A., Minakata, A. \& Sañudo, L. (2013). En torno a la intervención de la práctica educativa. Jalisco: Editada por la Unidad Editorial del Gobierno de Jalisco. Recuperado www.snte.org.mx/digital/049_00_opt.pdf
Casasbuenas, D.L., (2007). La entrevista médico-paciente: Perspectiva de análisis pragmático-discursivo. Universidad Autónoma de Barcelona, España. Recuperado de: www.tdx.cat/bitstream/10803/4210/1/lcd1d1.pd f

Casares, D., \& Siliceo, A. (2005). Planeación de vida y carrera: vitalidad personal y organizacional, desarrollo humano y crisis de madurez, asertividad y administración del tiempo. México: Editorial Limusa Recuperado de: https://books.google.com.mx/books/about/Plan eación_de_vida_y_carrera.ht ml?id

Colmenares, E.A., (2012). Investigación-Acción participativa: una metodología integradora del conocimiento y la acción. Voces y Silencios: Revista Latinoamericana de Educación,vol3(1) 102-115 Recuperado de: https://dialnet.unirioja.es/descarga/artículo/405 4232.pdf

Concha, H., (2013). Técnicas de entrevista y observación. Facultad de ciencias de la salud, Escuela de Psicología. Recuperado de:

https://psicomanuel.files.wordpress.com/2013/1 1/1-variables-interaccion- empatia-raport.pdf Costa, P., Alves, R., Neto, I., Marvão, P., Portela, M. \& Costa, M. J. (2014).

Associations between Medical Student Empathy and Personality: A MultiInstitutional Study. Study. PLoS ONE, 9.doi:10.1371/journalpone-0089254 Recuperado de:

Journals.plos.org/plosone/article?id=10.1371/jo urnal.pone...

Crisol, M.E. (2011). Diseño de cuestionarios: la opinión y la percepción del profesorado y de los estudiantes sobre el uso de las metodologías activas en la universidad. Revista profesorado (revista de curriculum y formación del $\begin{array}{llll}\text { profesorado) vol15 (2) 271-298 } & \end{array}$ Recuperado de: www.redalyc.org/pdf/567/56719129018.pdf 
Chen, D., Lew, R., Hershman, W. \& Orlander, J. (2007).A Cross-sectional Measurement of Medical Student Empathy. Journal of General Internal Medicine, 22.doi: $\quad 10.1007 / \mathrm{s} 11606-007-0298$ xRecuperado de: http://dx.doi.org/10.1007/s11606-007-0298-x www.scrip.org/(S(351jmbntvnsjt1 aadkposzje))/ reference/ReferencesPapers.a spx?ReferenceID=1584091

Chen D., Kirshenbaum, D. S., Yan.J., Kirshenbaum, E., \& Aseltine R. H. (2012).

Characterizing changes in student empathy throughout medical school. Medical Teacher, 34.doi: $\quad$ 10.3109/0142159X-2012-644600

Recuperado de: http://dx.doi.org/10.3109/0142159X-2012644600

www.tandfonline.com/doi/abs/10.3109/014215

9X.2012.644600? journalCode $=$ imte20

Chew, B. H., Zain, A. M., \& Hassan, F. (2013). Emotional intelligence and academic performance in first and final year medical students: a cross-sectional study. Medical Education, 13 (44), 1-10. Recuperado de http://www.biomedcentral.com/1472-

$6920 / 13 / 44$

Davis, M., (1996). Empatía: un enfoque psicológico social. Boulder, CO: Editorial Westview Press Recuperado de: http.//westviewpress.com/books/empathy/\&pre $\mathrm{v}=$ search

Delgado, S.G., (2008). Microtalleres de desarrollo personal: Una contribución para abordar los problemas de bajo rendimiento académico en la FES IZTACALA UNAM. Recuperado de: www.bib.uia.mx/tesis/pdf/014957/014957_00.p df

Espinoza, S., (2016). Tipos de muestreo. Recuperado de: www.bvs.hn/Honduras/Embarazo/Tipos.de.Mu estreo.Marzo.2016.pdf

Fernández, I., López, B., \& Márquez, M., (2008). Empatía: Medidas, teorías y aplicaciones en revisión. Universidad Autónoma de Madrid, España. Anales de psicología, vol. 24 (2), 284-298. Recuperado de:

https://es.scribd.com/doc/313610415/EmpatíaMedidas-teórias-y-aplicaciones-en-revisión-pdf ISSN-2444-4952

ECORFAN $^{\circledR}$ Todos los derechos reservados
Flick, U., (2004). Introducción a la investigación cualitativa. Editorial Morata Recuperado de: http://www.u-

cursos.cl/filosofia/2009/2/EDU203/1/material_ docente/bajar?id

Gallardo, L. S., (2011). Cambio de Actitud en la relación médico-paciente en el residente de medicina familiar. Posterior a una intervención educativa en bioética con enfoque participativo y reflexivo. Facultad de Medicina. Universidad Autónoma de Querétaro. Recuperado de: ri.uaq.mx/bitstream/123456789/760/1/RI00035 $0 . p d f$

García, B. \& Loredo, J. (2008). Análisis de la práctica educativa de los docentes: pensamiento, interacción y reflexión. Revista electrónica de investigación educativa volumen especial 2008 $2-15$. Recuperado de: www.scielo.org.mx/scielo.php?script=sci_artte xt\&pid...40412008000300006

García, B. \& Zendejas, L., (2008). Hacia un modelo de supervisión escolar para las primarias mexicanas. Instituto nacional para la evaluación de la educación. México, D. F. Recuperado de: www.oei.es/historico/pdf2/nuevo_modelo_supe rvición_escolar.pdf

Guerra, J.E., (2013). Plan UAS: consolidación institucional 2013-2017. Recuperado de: cpp.uas.edu.mx/archivos 1369097730.pdf

Hernández S. \& Mendoza P. (2008). Los Métodos Mixtos. Universidad Cesar Vallejo. Universidad de Celaya. Recuperado en: es.slideshare.net/conyas16/sampieri-metodosmixtos.

Hojat M. y Mangione S. (2001). Jefferson Scale of Physician Empathy. Health Policy Newsletter, 14(4): Article 5. Recuperado de http://jdc.jefferson.edu/hpn/vol14/iss4/5.

Hojat, M., Gonnella, J. S., Nasca, T. J., Mangione, S., Veloksi, J. J. y Magee M. (2002). The Jefferson Scale of Physician Empathy: Further Psychometric Data and Differences by Gender and Specialty at Item Level. Academic Medicine, 77 (10), 58-60. 
Hojat, M., Louis, D. Z., Maxwell, K. y Gonnella, J. S. (2011). The Jefferson Scale of Empathy (JSE): An Update. Healt Policy Newsletter, 24 (2). Recuperado de:http://jdc.jefferson.edu/cgi/viewcontent.cgi? article $=1727 \&$ context $=$ hpn

Howard, M., Navarro, S., Rivera, I., Zamorano, A. \& Díaz, V. P. (2013). Medición del nivel de orientación empática en el estudiantado de la Facultad de Odontología, Universidad de Costa Rica. Revista Universidad de Costa Rica,

15 ,

Recuperado

21-29.

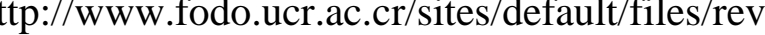
sta/Medición\%20del\%20nivel\%20de\%20orient ación\%20empática\%20en\%20e1\%20estudianta do\%20de\%20la\%20Facultad\%20de\%20Odonto logía

Jaramillo, N., (2009). Trato, Comunicación y Satisfacción: Percepción de los pacientes hospitalizados y cuidadores del trato y comunicación brindada por profesionales de salud en relación con sus niveles de satisfacción. Facultad de Psicología. Universidad de la Sabana. Colombia. Recuperado de: http://intellectum.unisabana.edu.co/bitstream/ha ndle/10818/2732/122082.pdf?sequence $=1$

Kane, G., Gotto, I., Mangione, S., West, S., \& Hojat, M. (2007). Jefferson Scale of Patients Perceptions of Physician Emphaty: Preliminary Psychometric Data. Department of Medicine, Jefferson Medical College of Thomas Jefferson University, Philadelphia, PA, USA.

Khademalhosseini, M., Khademalhosseini, Z., y Mahmoodian, F. (2014).

Comparison of empathy score among medical students in both basic and clinical levels. Jorurnal of Advances in Education \& Professinalism. Shiraz University of Medical Scienses, Shiraz Iram. Recuperado de: https://www.ncbi.nlm.nih.gov/pmc/articles/PM C4235551/

Márquez, A., (2014). Empatía y satisfacción de la "Relación médico-paciente" en la UMF No. 66 de Xalapa, Veracruz. Instituto Mexicano del Seguro Social, Unidad de medicina familiar No. 66. Xalapa, Veracruz, Universidad Veracruzana. Recuperado de: www.uv.mx/favem2014/files2014/06/Aracely.p df
Martí, S., (2012). Las causas del miedo a la atención dental. Universidad Nacional de Cuyo, Facultad de Odontología. Recuperado de: http://argentinainvestiga.edu.ar/noticia.php.\&id: 1434

Mendoza, R., (2006). Investigación Cualitativa y Cuantitativa. Diferencias y Limitaciones. Piura, Perú. Recuperado de: http://www.monofrafías.com/trabajo38/investig ación-cualitativa/investigación cualitativa2.

Miller, C., (2010). Estrategias de entrevista. Rapport y Empatía. Recuperado de: https://books.google.com.mx/books?id=h8WU BQAAQBAJ\&pg=PA168\&lpg=P

A168\&dq=miller+2010+rapport\&source=bl\&ot $\mathrm{s}=1 \mathrm{DxB} 4 \mathrm{HK}$ ldf\&sig=DG_srfJAc5Ob2jzFFTc7 LxZFFFI\&h

Misra, A.D., Isaacson, J. H., Kohn, M., Hull, A. L., Hojat, M., Papp, K. K. y Calabrese, L. (2012). Improving empathy of physicians through guided reflective writing. International Journal of Medical Education, 3, 7177. doi: 10.5116/ijme.4f7e.e332Recuperado de: http://dx.doi.org/10.5116/ijme.4f7e.e332 www.ijme.net/archive/3/improving- empathyof-physicians/

Nunes, P., Williams, S., \& Stevenson, K. (2011). A study of empathy decline in students from five health disciplines during their first year or training. International Journal of Medical Education, 2,12-17. doi:10.5116/ijme.4d47.ddb0

Recuperado de: http://dx.doi.org/10.5116/ijme.4d47.ddb0https:/ /www.ijme.net/.../2/empathy- decline-in-firstyear-students/

Latorre, A., (2003). La Investigación-Acción: conocer y cambiar la práctica educativa. España: Editorial GRAÓ Recuperado de: https://es.scribd.com/doc/27686077/Que-es-laInvestigación-Acción

Oviedo, M. (2011). Empatía de estudiantes en formación en la facultad de Odontología de la Universidad de Carabobo. (Tesis inédita de Doctorado). Universidad Autónoma de Madrid, Carabobo, España. Recuperado de: https://dialnet.unirioja.es/servlet/tesis?codigo $=3$ 0925 \&orden $=0$ \&info $=$ link 
Pimienta, J., (2007). Metodología constructivista, guía para la planeación docente. México: Editorial Pearson Educación. Recuperado de: https://bibliotecafcalbatros.files.wordpress.com/ 2014/05/constructivismo- pimienta.pdf

Prabhu S., Kumar V. S., Prasanth S. S. \& Kishore S. (2014). Standing in patients' shoes survey on empathy among dental students in India. Journal of Education and Ethics in Dentistry, 4 (2), 69-73. doi: 10.4103/09747761.148990Recuperado de: http://dx.doi.org/10.4103/0974-

7761.148990http://www.jeed.in/article.asp?issn =0974-761;year $=2014 ; \ldots$

Pulido, J.E., (2014). Investigación Cualitativa, aspectos fundamentales; Programa de Postgrado Gerencia Educacional, Aprender Haciendo y Rectificando.Recuperadodehttps//prezi.com/qw utdc5lrvji/investigación- cualitativa/

Rivera, I., Arratia, R., Zamorano, A., \& Díaz, V.P. (2011). Evaluación del nivel de orientación empática en estudiantes de Odontología. Measurement of empatheticorientation in Dentistry students. Facultad de Odontología, Universidad FinisTerrae, Santiago de Chile ISSN electrónico: 2011-7531

$\begin{array}{llll}\text { Vol } & 27, & N^{\circ} & 1\end{array}$

Recuperado

de:http://rcientificas.uninorte.edu.co/index.php/ salud/article/viewFile/1887/2142

Rodríguez, M. (2004). Teoría del Aprendizaje Significativo. Mapas Conceptuales: Teoría, Metodología, Tecnología Proc de la primera Int conferencia sobre mapas conceptuales A. J. Cañas, J.D. Novak, F.M. González. España: Editorial Pamplona Recuperado de: cmc.ihmc.us/papers/cmc2004-290.pdf

Rojas, S., Castañeda, B. \& Parraguez, I. (2009). Orientación empática de los estudiantes de las escuelas de Kinesiología en chile/ orientación empática del terapeuta físico de dos escuelas de chile. Revista Educ. med 12 (2) 103-109 Recuperado

de:

http://www.tesis.uchile.cl/Tesis/uchile/2006/cas taneda_s/sources/castaneda_s.pdf
Romero, C. (2005). La categorización un aspecto crucial en la investigación cualitativa. Revista de investigaciones Cesmagvol11(11) 112-118.

Salazar, M.C. (2012). Tesis de investigación. Traducción de documento de Lewin, Kurt., (1946).Action Research and Minority Problems. Journal of Social Issues, vol 2(4) 34-46. Recuperado de: file///c:/users/HP/Documents/Doctorado/Refere ncias Biblio-Feb-15/Salazar,M2012

Samper, G. P. Díez, C. I. \& Martí, V. M. (1998). Razonamiento moral y Empatía. Universitat de Valencia. I Jornadas de psicología del pensamiento. Universidad de Santiago de Compostela, 389-404 Recuperado de: http://roderic.uv.es/bitstream/handle/10550/311 74/Razonamiento\%20moral\%20y\%20empatía. pdf? sequence $=1 \&$ isAllowed $=\mathrm{y}$

Scott, (2007). Enfoques cuantitativo, cualitativo y mixto de la investigación.

Recuperado de: es.slideshare.net/wbulege/enfoques-

cuantitativo-cualitativo- $\quad y$-mixto-de-lainvestigación Recuperado de: http://es.slideshare.net/wbulege/enfoquescuantitativo-cualitativo-y-mixto-de- lainvestigación

Schwartz, B. \& Bohay, R. (2011). Can Patients Help Teach Professionalism and Empathy to Dental Students? Adding Patient Videos to a Lecture Course. Journal of Dental Education, 76 (2), 174-184. Recuperado de: http://www.jdentaled.org/content/76/2/174.abst ract

Shapiro, J., Morrison, E. H. y Boker, J. R. (2004). Teaching Empathy to First Year Medical Students: Evaluation of an Elective Literature and Medicine Course. Education for Health, 17 (1), 73-84. doi: 10.1080/13576280310001656196 Recuperado de:

https://www.ncbi.nlm.nih.gov/pubmed/1520347 6

Sherman, J. J. \& Cramer, A. (2005). Measurement of Changes in Empathy During Dental School. Journal of Dental Education, 69 (3), 338-345.

Recuperadode:http://www.jdentaled.org/content /69/3/338.abstract 
Silva, M. G., Arboleda, J. y Díaz, V. P. (2013). Orientación empática en estudiantes de odontología de la Universidad Central del Este. Odontoestomatología, 15 (22), 24-33. Recuperado de: http://www.scielo.edu.uy/pdf/ode/v15n22/v15n 22a04.pdf

Strauss, \& Corbin, (2002). Bases de la investigación cualitativa. Medellín: Universidad de Antioquia. Recuperado de:

http://www.dandrosh.com.mx/.../Bases\%20de\% 20la\%20investigación\%20cua litativa\%20

Suardíaz, P., (2011). Relación médico-paciente y tecnología médica: Una visión personalista. Revista del centro de Bioética Juan Pablo II Vol 11 (1) 1-2 Recuperado de: http://www.cbioetica.org/revista/112/sup_112.p df

Van Manen, M., (2010). El tacto en la enseñanza: el significado de la sensibilidad pedagógica. España: Editorial Paidós. Recuperado de: http://memsupn.weebly.com/uploads/6/0/0/7/60 077005/el_tacto_en_la_enseñ anza.pdf

Vázquez, J.Y., (2013). Teorías del aprendizaje Ausubel-Bruner. Actividad Docente del módulo IV. Teorías del aprendizaje del componente Docente IPSM Recuperado de:http://es.slideshare.net/josevazquez7503/teor ias-del- aprendizaje-24359252

Álvarez, J. L. (2004). Cómo hacer investigación cualitativa: Fundamentos y metodología. México: Editorial Paidós.

Ausubel, D.P, Novak, J.D. \& Hanesian, H. (2014). Psicología Educativa: Un punto de vista cognoscitivo. México: Editorial Trillas. 1983 (reimp. 2014).

Ausubel, D., (2002). Adquisición y retención del conocimiento: una perspectiva cognitiva. Barcelona: Editorial Paidós.

Denzin, N., \& Lincoln, Y. (2012). Manual de Investigación Cualitativa. España: Editorial Gedisa.
García, G. V., (2013). "La importancia de la Empatía en la relación médico-paciente en la UMF 249 del Instituto Mexicano del Seguro Social mediante la Escala de Jefferson" Unidad de Medicina Familiar 249.Tlaxomulco, Estado de México. Universidad Autónoma de México.

García, M. P. S., \& Torreira, M. G. (2020). Enseñar, aprender y evaluar competencias clínicas en el Grado de Odontología: una propuesta innovadora. Revista de Investigación Educativa Universitaria, 3(1), 13-24.

González, A. M. (1996). El enfoque centrado en la persona. Aplicaciones a la educación. México: Editorial Trillas.

Gutiérrez, R. (2005). Psicología. México: Editorial Esfinge.

Gutiérrez, R., (1999). Introducción a la didáctica, para profesores del nivel medio superior. México: Esfinge.

Hernández S., Fernández C. \& Baptista L. (2006). Metodología de la Investigación. México: Editorial Mc Graw Hill.

Hoffman, M. L. (2002). Desarrollo Moral y Empatía. Barcelona: Idea Books, S.A Lafarga, J. \& Gómez, J. (2003). Desarrollo del potencial humano. Aportaciones de una psicología humanista. Tomo 1. México: Trillas.

Macedo, L. L., Silva, A. M. R., Silva, J. F. M. D., Haddad, M. D. C. F. L., \& Girotto, E.(2020). A cultura em torno da segurança do paciente na atenção primária à saúde: distinções entre categorias profissionais. Trabalho, Educação e Saúde, 18(1).

Martínez, M., (2006). Ciencia y Arte en la metodología cualitativa. México:Editorial Trillas.

Martínez, M., (2008). Epistemología y metodología cualitativa en ciencias sociales. México:Editorial Trillas.

Martínez, M., (2011). Paradigmas emergentes y ciencias de la complejidad. Universidad Simón Bolivar, Caracas. Opción, 27(65), 45-80. Maslow, A.H. (2002). La Amplitud Potencial de la Naturaleza Humana. México: Editorial Trillas. 
Moreno, S., (1979). La educación centrada en la persona. México: Editorial Manual Moderno.

Quitmann, H., (1989). Psicología humanista. Conceptos fundamentales y trasfondo filosófico. Barcelona: Editorial Herder.

Ramírez, M. (2011); Síntesis Ejecutiva del Plan de Desarrollo de la Facultad de Odontología 2011-2014. Universidad Autónoma de Sinaloa. México: Autor.

Rogers, C. (1985). Terapia, personalidad y relaciones interpersonales. Buenos Aires: Editorial Nueva Visión.

Rogers, C. (1987). El camino del ser. Barcelona: Editorial Kairós.

Rogers, C. (1990). Psicoterapia centrada en el cliente. México: Editorial Paidós. Rogers, C. (1991). Libertad y creatividad en la educación en la década de los ochenta. Barcelona: Editorial Paidós.

Rogers, C. (1993). Grupos de encuentro. Buenos Aires: Editorial Amorrortu. Salomón, E.L. (2006): "Caracterización de las actitudes del maestro y su influencia en el estrés del estudiante de la carrera de medicina de la Universidad Autónoma de Sinaloa". México.

Velasco, L., (2003). Educación y Enfoque Centrado en el estudiante. "Prometeo" México. $35,12-13$ 